\title{
PEMANFAATAN VERMIKOMPOS UNTUK PRODUKSI BIOMASSA LEGUM PENUTUP TANAH DAN INOKULUM FUNGI MIKORIZA ARBUSKULA
}

\author{
Abimanyu D. Nusantara ${ }^{1}$, C. Kusmana ${ }^{2}$, I. Mansur ${ }^{3}$, L.K. Darusman ${ }^{4}$, dan Soedarmadi ${ }^{5}$ \\ ${ }^{1}$ Mahasiswa Program Studi Ilmu Pengetahuan Kehutanan Sekolah Pascasarjana Institut Pertanian Bogor \\ (IPB) dan Dosen Jurusan Agroteknologi Fakultas Pertanian Universitas Bengkulu \\ ${ }^{2}$ Departemen Ekologi Hutan, Fakultas Kehutanan, IPB \\ ${ }^{3}$ Departemen Silvikultur, Fakultas Kehutanan, IPB \\ ${ }^{4}$ Departemen Kimia, Fakultas Matematika dan Ilmu Pengetahuan Alam, IPB \\ ${ }^{5}$ Departemen Nutrisi Ternak, Fakultas Peternakan, IPB \\ abimanyu.dn@gmail.com.
}

\begin{abstract}
[THE USE OF VERMICOMPOST FOR BIOMASS PRODUCTION OF LEGUME COVER CROP AND INOCULUM OF ARBUSCULAR MYCORRHIZAL FUNGUS]. Vermicompost is an organic fertilizer produced through the digestive system and microorganism inside the earthworm gut. Vermicompost is recognized to have positive effects on the plant growth and development of mycorrhizal symbiosis. The study was aimed to determine the optimum size (diameter and weight) of vermicompost for producing biomass of legume cover crop (LCC) and inoculum of arbuscular mycorrhiza fungus (AMF) of G. etunicatum. A glasshouse experiment was arranged in a randomized block design, involving different diameter size and weight of vermicompost as the treatments. Results showed that vermicompost is a potential substitute to inorganic fertilizer for production of LCC biomass and AMF inoculum.Vermicompost applied with diameter $<250 \mu \mathrm{m}$ weighing $150-172 \mathrm{mg}$ produced the highest root dry weight of LCC, root colonization, and number of spores of G. etunicatum. A linear relation was found between root colonization and number of spores of G. etunicatum.
\end{abstract}

Keyword: G. etunicatum, P. phaseoloides, vermicompost, inoculum production

\begin{abstract}
ABSTRAK
Vermikompos merupakan pupuk organik yang diproduksi dengan bantuan sistem pencernaan dan mikro-organisme dalam usus cacing tanah. Vermikompos diketahui berpengaruh positif terhadap pertumbuhan tanaman dan perkembangan simbiosis mikoriza. Penelitian ini bertujuan mencari ukuran garis tengah dan bobot vermikompos yang optimal untuk menghasilkan biomasa tanaman kudzu dan inokulum fungi mikoriza arbuskula (FMA) G. etunicatum. Percobaan rumah kaca dilaksanakan berdasarkan rancangan acak kelompok dengan kombinasi ukuran garis tengah dan bobot vermikompos sebagai perlakuan. Hasil percobaan menunjukkan bahwa vermikompos berpotensi positif sebagai pengganti pupuk buatan untuk meningkat-kan produksi biomassa tanaman kudzu dan inokulum FMA G. etunicatum. Vermikompos dengan ukuran diameter $<250 \mu \mathrm{m}$ bobot $150-172 \mathrm{mg}$ menghasilkan bobot kering akar dan kolonisasi FMA di akar tanaman kudzu serta jumlah spora $G$. etunicatum tertinggi dibandingkan perlakuan lainnya. Kolonisasi FMA di akar kudzu berkorelasi positif dengan jumlah spora G. etunicatum.
\end{abstract}

Kata kunci: G. etunicatum, P. phaseoloides, vermicompost, produksi inokulum 


\section{PENDAHULUAN}

Belakangan ini semakin kuat keinginan untuk mengurangi penggunaan bahan pupuk buatan dan secara bertahap menggantinya dengan pupuk organik. Vermikompos merupakan pupuk organik yang dihasilkan dari proses dekomposisi sisa-sisa tumbuhan dan hewan dalam sistem pencernaan cacing tanah yang kaya jasad renik, enzim, dan berbagai senyawa organik lainnya. Proses dekomposi demikian ini mempercepat humifikasi bahan organik dan menghasilkan bahan dengan karakter fisikokimia dan biologi yang sangat berbeda dengan bahan dasarnya. Vermikompos diketahui kaya akan sumber hara tersedia yang dibutuhkan tanaman (Ferreras et al., 2006) serta hormon tumbuh, enzim, dan jasad renik (Ndegwa and Thompson, 2001). Seperti halnya bahan organik lainnya, vermikompos memiliki kapasitas tukar kation tinggi sehingga mampu memfasilitasi pertukaran hara untuk meningkatkan pertumbuhan dan hasil tanaman (Bachman and Metzger, 2008).

Tanaman kudzu (Pueraria phaseoloides) tergolong tanaman legum merambat yang digunakan sebagai penutup tanah di bawah tegakan karet, kopi, kelapa, kakao dan tanaman tahunan lainnya. Dengan kemampuannya menambat nitrogen, kudzu mempunyai peran penting dalam memperbaiki sifat fisik tanah maupun dalam meningkatan ketersediaan hara terutama nitrogen bagi tanaman utama. Namun, sebagai tanaman legum, kudzu memerlukan banyak unsur fosfor dari dalam tanah dan dari pupuk untuk memfiksasi $\mathrm{N}_{2}$ dari atmosfir. Vermikompos merupakan penyedia $\mathrm{P}$ organik yang harus dimineralisasikan terlebih dulu agar dapat dimanfaatkan tanaman.Mineralisasi $\mathrm{P}$ organik dapat berlangsung jika dalam tanah terdapat jasad renik perombak yang salah satu diantaranya adalah fungi mikoriza arbuskula (FMA).

Fungi mikoriza arbuskula (FMA) termasuk dalam filum Glomeromikota dan diketahui berperan penting dalam membantu serapan hara tanaman, khususnya fosfor (P), meningkatkan daya tahan tanaman terhadap cekaman biotik dan abiotik, dan menyumbangkan sejumlah karbon untuk proses agregasi partikel tanah (Smith and Read, 2008). Informasi mengenai respon FMA terhadap vermikompos masih sangat terbatas dan seringkali saling bertentangan. Vermikompos dilaporkan berpengaruh positif (Cavender et al., 2003), netral (Sainz and Taboada, 1996), atau negatif (Sainz et al., 1998) terhadap perkembangan FMA. Perbedaan karakter fisiko-kimia-biologi vermikompos, tanaman inang, dan jenis FMA menjadi penyebab perbedaan respon FMA terhadap vermikompos tersebut. Karakter fisik yang masih sedikit mendapatkan perhatian ialah ukuran diameter butir. Ukuran butir menentukan luas permukaan sebuah bahan, semakin kecil ukuran butir semakin besar luas permukaan untuk pertukaran hara atau proses lain (Havlin et al., 2005).

Tanaman kudzu juga tergolong sesuai untuk produksi inokulum FMA karena banyak membentuk akar adventif. Oleh karena vermikompos selain mengandung $\mathrm{P}$ organik juga mengandung auksin yang diperlukan untuk pembentukan akar tanaman (Canellas et al., 2003), maka pemberian vermikompos diharapkan meningkatkan jumlah akar untuk dapat dikolonisasi oleh FMA dan menghasilkan produksi inokulum yang tinggi (Feldman et al., 2009). Sejauh ini masih sedikit informasi mengenai manfaat vermikompos untuk produksi biomassa legum penutup tanah dan inokulum FMA G. etunicatum dalam kultur pot terbuka. Penelitian ini bertujuan untuk mendapatkan ukuran (diameter dan bobot) optimal vermikompos untuk produksi biomassa legum penutup tanah dan inokulum FMA G. etunicatum pada pot terbuka dengan tanaman kudzu (Puerariaphaseoloides) sebagai tanaman mitra simbiosis dan zeolit sebagai medium tumbuh.

\section{METODE PENELITIAN}

Spora G. etunicatum NPI-126, benih kudzu, dan zeolit diperoleh dari Lab. Bioteknologi Hutan dan Lingkungan, Pusat Penelitian Sumberdaya Hayati dan Bioteknologi, IPB. Karakter morfologi $G$. etunicatum yang digunakan dalam penelitian ini adalah spora tunggal tidak membentuk tandan, tidak memiliki dudukan spora, dan hanya dengan satu tangkai spora. Bentuk spora bulat dengan ukuran diameter $140 \mu \mathrm{m}$, berwarna kuning sampai kuning coklat. Dinding terluar permukaannya agak kasar, berwarna hyaline, tebal $4 \mu \mathrm{m}$. Dinding terdalam berwarna kuning coklat dengan ketebalan $6 \mu \mathrm{m}$. Hifanya lurus dan panjang dengan percabangan bertipe huruf $\mathrm{H}$, menyebar di dalam kortek akar, intensif menyerap warna biru tryphan, vesikel berbentuk lonjong. Spora G. etunicatum diperbanyak dengan metoda kultur tunggal menggunakan tanaman inang kudzu dengan zeolit sebagai substrat dan larutan pupuk buatan yang mengandung $25 \% \mathrm{~N}$, $1.09 \% \mathrm{P}$, dan $20 \% \mathrm{~K}$ sebagai sumber hara. Vermikompos diperoleh dari Lab. Teknologi Hasil Ternak, Fak. Peternakan IPB.Vermikompos tersebut mengandung $34.5 \% \mathrm{C}, 1.8 \% \mathrm{~N}, 1.1 \% \mathrm{P}$, 
$1.5 \% \mathrm{~K}, 3.6 \% \mathrm{Ca}, 1.5 \% \mathrm{Mg}, \mathrm{Fe} 1025.1 \mathrm{mg} \mathrm{kg}^{-1}$, $\mathrm{Zn} 206.8 \mathrm{mg} \mathrm{kg}^{-1}, 1028.6 \mathrm{mg} \mathrm{kg}^{-1}$, pH 5.7, kapasitas tukar kation $54.9 \mathrm{mg} \mathrm{kg}^{-1}$ dan daya hantar listrik $22.7 \mu \mathrm{S} \mathrm{cm}^{-1}$.

Sebelum penanaman, benih dicuci dan didisinfeksi dengan larutan $\mathrm{NaOCl}$ selama 5 menit, dicuci kembali dengan air mengalir sampai bau $\mathrm{NaOCl}$ hilang. Benih kemudian direndam dalam air panas selama 20 menit dan dikecambahkan dalam media zeolit steril. Pada saat berdaun dua, bibit kudzu diinokulasi dengan 20 buah spora G. etunicatum pada akarnya dan ditanam dalam pot plastik berisi $175 \mathrm{~g}$ zeolit bercampur sumber fosfor yang diuji.

Percobaan disusun dalam rancangan acak kelompok dengan 6 ulangan yang masing-masing terdiri atas 3 pot plastik sebagai satuan percobaan. Sumber fosfor yang diuji adalah larutan pupuk buatan (kontrol), vermikompos berdiameter $<250$ $\mu \mathrm{m}$ dengan bobot 50, 100, 150, dan $200 \mathrm{mg}$, vermikompos berdiameter 250 - $500 \mu \mathrm{m}$ dengan bobot 50 , 100, 150, dan $200 \mathrm{mg}$, dan vermikompos berdiameter $>500 \mu \mathrm{m}$ dengan bobot 50, 100, 150, dan $200 \mathrm{mg}$.

Pupuk buatan dalam bentuk larutan dengan kadar $1 \mathrm{~g} \mathrm{~L}^{-1}$ diberikan seminggu sekali sebanyak $11 \mathrm{~mL}$ hanya pada perlakuan kontrol. Vermikompos diberikan pada saat tanam dengan ukuran dan bobot sesuai dengan perlakuan yang diuji. Tanaman dipelihara selama 12 minggu dengan disiram air destilasi setiap dua hari sekali sebanyak $11 \mathrm{~mL}$. Selama percobaan penanggulangan hama dan penyakit tidak dilakukan dengan menggunakan pestisida.

Pada umur 12 minggu setelah tanam (mst) percobaan dihentikan dan dua pot plastik diambil secara acak untuk dibongkar. Bagian atas tanaman kudzu dipotong dan dipisahkan dari akarnya. Akar dicuci bersih, ditimbang bobot basahnya total, kemudian secara acak sebagian akar muda diambil dan ditimbang bobot basah sedangkan sisanya dimasukkan ke dalam oven bersuhu $80{ }^{\circ} \mathrm{C}$. Bobot kering akar kemudian digunakan untuk menghitung bobot kering akar secara keseluruhan dan rata-rata bobot kering akar diperoleh dengan membagi dua bobot kering akar total tersebut.

Potongan akar muda yang telah dibersihkan kemudian direndam semalam dalam dalam $\mathrm{KOH}$ $10 \%$. Keesokan harinya akar dicuci bersih dengan air mengalir dan selanjutnya direndam semalam dalam larutan campuran tinta dan cuka komersial $5 \%$ yang dibuat dengan cara mencampur $200 \mathrm{~mL}$ cuka komersial (asam asetat $25 \%$ ) dan $50 \mathrm{~mL}$ tinta tulis Quink warna biru dalam labu takar. Kolonisasi akar dihitung berdasarkan proporsi kenampakan bidang pandang mikroskop yang memperlihatkan struktur mikoriza (arbuskula, hifa, dan vesikel) pada akar terhadap keseluruhan bidang pandang yang diamati.

Tanaman pada satu pot yang tersisa dibiarkan mengering dan tidak disiram selama 30 hari. Spora G. etunicatum dalam substrat dipindahkan dengan metode saring basah yang kemudian diikuti dengan sentrifugasi dalam larutan sukrosa. Spora yang tersaring kemudian dihitung dengan penghitung tangan (handcounter) dengan bantuan mikroskop.

Hasil pengamatan dianalisis dengan sidik ragam (ANOVA) dan Uji Duncan menggunakan CoStat v6.400. Transformasi Box-Cox menggunakan Minitab v15.1 dilakukan pada data yang tidak memenuhi asumsi kenormalan galat. Analisis regresi antar peubah tanaman dan FMA dianalisis menggunakan Microsoft Excel 2010.

\section{HASIL DAN PEMBAHASAN}

Diameter dan bobot vermikompos berpengaruh sangat nyata $(\mathrm{p}<0.01)$ terhadap bobot kering akar, pucuk, dan total tanaman kudzu, dan kolonisasi akar, dan berpengaruh nyata $(\mathrm{p}<0.05)$ terhadap jumlah spora $G$. etunicatum. Secara umum vermikompos yang diberikan, kecuali diameter $>500 \mu \mathrm{m}$, menghasilkan rata-rata biomassa tanaman kudzu (bobot kering akar, pucuk dan total) lebih tinggi dibanding kontrol (Tabel 1). Hal ini menunjukkan bahwa vermikompos merupakan bahan alami yang sangat potensial untuk memproduksi biomassa legum penutup tanah dan berpotensi menggantikan pupuk buatan dalam penyediaan hara tanaman. Sekalipun, vermikompos berdiameter besar $(>500$ $\mu \mathrm{m})$ relatif lebih rendah dalam menghasilkan biomassa tanaman dibanding dengan berdiameter lebih kecil, dalam jangka panjang ukuran besar ini lebih menguntungkan karena bahan yang hilang akibat pencucian menjadi kecil dan unsur hara dilepaskan lebih lambat.

Berdasarkan analisis regresi, bobot vermikompos dari masing-masing diameter membentuk hubungan yang linier positif dengan bobot kering tanaman kudzu (Gambar 1, 2 dan 3) yang berarti bahwa bobot vermikompos masih dapat ditingkatkan untuk menghasilkan biomassa tanaman kudzu yang lebih tinggi. Vermikompos merupakan bahan yang telah terseleksi dan mengalami pengkayaan selama diproses dalam usus cacing tanah sehingga memiliki karakteristik fisikokimia yang jauh berbeda dibandingkan bahan aslinya. Vermikompos, seperti halnya kompos lainnya, merupakan sumber hara 
NUSANTARA et al.

Tabel 1. Rata-rata biomassa tanaman kudzu, aras kolonisasi, dan jumlah spora G. etunicatum pada 12 mst

\begin{tabular}{|c|c|c|c|c|c|c|c|c|c|c|}
\hline \multirow{3}{*}{$\begin{array}{l}\text { Perlakuan } \\
\text { Hyponex Merah }\end{array}$} & \multicolumn{6}{|c|}{ Bobot kering (mg) } & \multirow{2}{*}{\multicolumn{2}{|c|}{$\begin{array}{c}\text { Kolonisasi } \\
\text { akar (\%) }\end{array}$}} & \multirow{2}{*}{\multicolumn{2}{|c|}{$\begin{array}{c}\text { Jumlah } \\
\text { spora }\end{array}$}} \\
\hline & \multicolumn{2}{|c|}{ Akar } & \multicolumn{2}{|c|}{ Pucuk } & \multicolumn{2}{|c|}{ Total } & & & & \\
\hline & 196 & $\mathrm{c}$ & 865 & $\mathrm{c}$ & 1061 & $\mathrm{c}$ & 99 & $\mathrm{a}$ & 958 & bc \\
\hline Vermikompos $<250 \mu \mathrm{m} 50 \mathrm{mg}$ & 160 & de & 615 & e & 775 & $\mathrm{f}$ & 86 & $\mathrm{bc}$ & 1528 & $a b c$ \\
\hline Vermikompos $<250 \mu \mathrm{m} 100 \mathrm{mg}$ & 203 & $\mathrm{c}$ & 785 & $\mathrm{~d}$ & 987 & cde & 99 & a & 2279 & $\mathrm{a}$ \\
\hline Vermikompos $<250 \mu \mathrm{m} 150 \mathrm{mg}$ & 272 & $\mathrm{ab}$ & 1026 & $\mathrm{a}$ & 1298 & $\mathrm{a}$ & 99 & a & 2295 & a \\
\hline Vermikompos $<250 \mu \mathrm{m} 200 \mathrm{mg}$ & 306 & $\mathrm{a}$ & 996 & $\mathrm{ab}$ & 1302 & $\mathrm{a}$ & 97 & a & 2449 & $\mathrm{a}$ \\
\hline Vermikompos $250-500 \mu \mathrm{m} 50 \mathrm{mg}$ & 143 & e & 591 & e & 734 & $\mathrm{f}$ & 65 & $\mathrm{~d}$ & 1316 & $a b c$ \\
\hline Vermikompos 250 - $500 \mu \mathrm{m} 100 \mathrm{mg}$ & 190 & $\mathrm{~cd}$ & 770 & $\mathrm{~d}$ & 960 & de & 89 & $\mathrm{~b}$ & 1601 & abc \\
\hline Vermikompos 250 - $500 \mu \mathrm{m} 150 \mathrm{mg}$ & 257 & $\mathrm{~b}$ & 786 & $\mathrm{~d}$ & 1042 & $\mathrm{~cd}$ & 92 & $\mathrm{ab}$ & 1910 & abc \\
\hline Vermikompos $250-500 \mu \mathrm{m} 200 \mathrm{mg}$ & 284 & $a b$ & 968 & $a b$ & 1252 & $a b$ & 98 & a & 1946 & $a b$ \\
\hline Vermikompos $>500 \mu \mathrm{m} 50 \mathrm{mg}$ & 135 & $\mathrm{e}$ & 583 & $\mathrm{e}$ & 718 & $\mathrm{f}$ & 50 & $\mathrm{e}$ & 779 & $\mathrm{c}$ \\
\hline Vermikompos $>500 \mu \mathrm{m} 100 \mathrm{mg}$ & 176 & $\mathrm{~cd}$ & 753 & $\mathrm{~d}$ & 930 & e & 63 & $\mathrm{~d}$ & 967 & bc \\
\hline Vermikompos $>500 \mu \mathrm{m} 150 \mathrm{mg}$ & 240 & $\mathrm{~b}$ & 781 & $\mathrm{~d}$ & 1021 & $\mathrm{~cd}$ & 80 & $\mathrm{c}$ & 1297 & $a b c$ \\
\hline Vermikompos $>500 \mu \mathrm{m} 200 \mathrm{mg}$ & 259 & $\mathrm{~b}$ & 924 & bc & 1184 & $\mathrm{~b}$ & 81 & $\mathrm{c}$ & 1317 & $\mathrm{abc}$ \\
\hline F hitung & 19.44 & $* *$ & 30.86 & $* *$ & 46.25 & $* *$ & 51.08 & $* *$ & 2.49 & $*$ \\
\hline KK & 4 & & 8 & & 8 & & 7 & & 9 & \\
\hline 1 Box-Cox & 0,25 & & 1 & & 1 & & 1 & & $\log x$ & \\
\hline
\end{tabular}

Keterangan: $\operatorname{tn}=p>0.05, *=p<0,05, * *=p<0.01$; Rata-rata sekolom diikuti huruf sama berarti berbeda tidak nyata pada DMRT $(\alpha=5 \%)$.

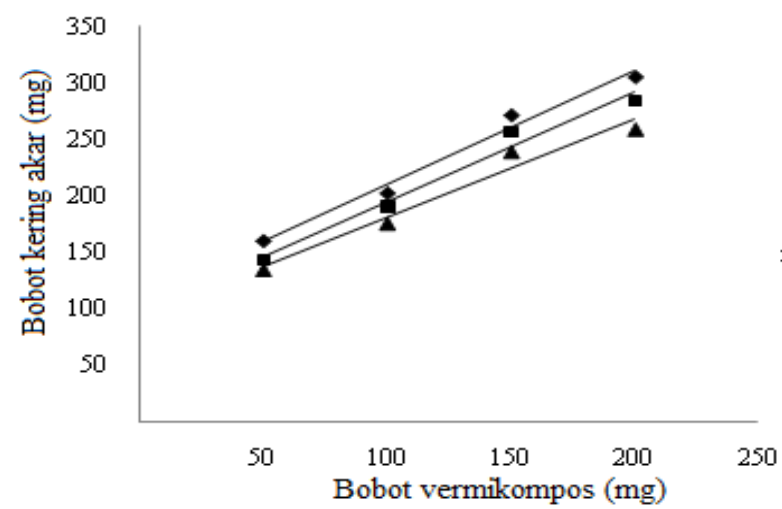

Gambar 1. Hubungan antara bobot vermikompos dan bobot kering akar tanaman kudzu umur 12 mst. Garis regresi diameter vermikompos $<250 \mu \mathrm{m}$ (•) $\mathrm{y}=1.02 \mathrm{x}+108.2\left(\mathrm{r}^{2}=0.98\right) ; 250-500 \mu \mathrm{m}$ (ש) $\mathrm{y}=0.98 \mathrm{x}+96.5\left(\mathrm{r}^{2}=0,98\right) ;$ dan $>500 \mu \mathrm{m}$ (A) $\mathrm{y}=0.88 \mathrm{x}+93.66\left(\mathrm{r}^{2}=0.97\right)$.

yang dapat digunakan untuk meningkatkan pertumbuhan tanaman dan simbiosis MA. Vermikompos dilaporkan dapat digunakan untuk meningkatkan biomassa berbagai jenis tanaman seperti kacang hijau (Vigna radiata) (Singh and Sharma, 2003), sorghum (Cavender et al., 2003) atau cabai (Douds et al., 1997). Karakter fisikokimia dan biologi vermikompos, misalnya diameter butir, kadar hara, nisbah N/P, kandungan senyawa biologis aktif, enzim, dan populasi jasad renik menentu-

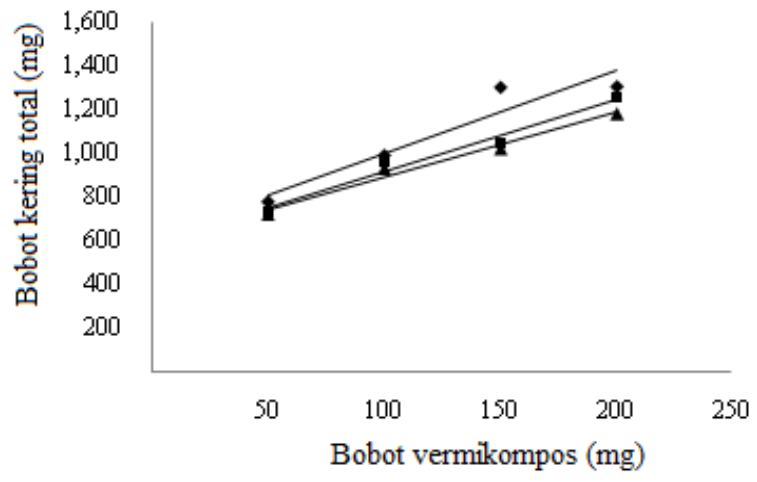

Gambar 2. Hubungan antara bobot vermikompos dan bobot kering pucuk tanaman kudzu umur $12 \mathrm{mst}$. Garis regresi diameter vermikompos $<250 \mu \mathrm{m}$ (४) $\mathrm{y}=2.77 \mathrm{x}+509.0\left(\mathrm{r}^{2}=0.86\right) ; 250-500 \mu \mathrm{m}$ (घ) $\mathrm{y}=2.29 \mathrm{x}+491.7\left(\mathrm{r}^{2}=0.92\right) ;$ dan $>500 \mu \mathrm{m}$ (A) $\mathrm{y}=2.11 \mathrm{x}+497.1\left(\mathrm{r}^{2}=0.94\right)$.

kan kemampuan vermikompos untuk meningkatkan pertumbuhan tanaman dan simbiosis MA di lapangan dan rumah kaca (Roldan and Albaladejo, 1993).

Ditinjau dari aspek produksi inokulum $G$. etunicatum, vermikompos merupakan sumber hara yang mampu menghasilkan aras kolonisasi sama baiknya dengan pupuk buatan, namun dengan jumlah spora yang lebih tinggi (Tabel 1). FMA selama ini diketahui hanya memanfaatkan sumber 


\section{VERMIKOMPOS UNTUK PRODUKSI LEGUM DAN INOKULUM MIKORIZA ARBUSKULA}

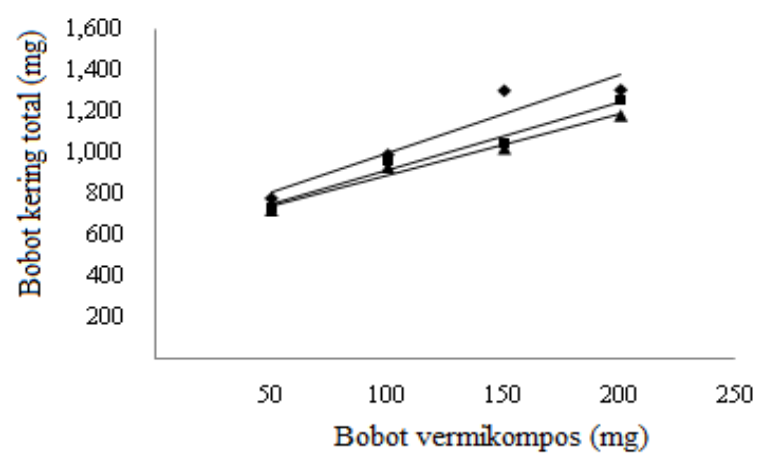

Gambar 3. Hubungan antara bobot vermikompos dan bobot kering total tanaman kudzu umur 12 mst. Garis regresi diameter vermikompos $<250 \mu \mathrm{m}$ (४) $\mathrm{y}=3.79 \mathrm{x}+617.3\left(\mathrm{r}^{2}=0.90\right) ; 250-500 \mu \mathrm{m}$ (ש) $\mathrm{y}=3.27 \mathrm{x}+588.2\left(\mathrm{r}^{2}=0.97\right) ;$ dan $>500$ $\mu \mathrm{m}(\boldsymbol{\Delta}) \mathrm{y}=2.98 \mathrm{x}+590.8\left(\mathrm{r}^{2}=0.98\right)$.

$\mathrm{P}$ anorganik dari medium tumbuh atau pupuk. Namun, belakangan diketahui bahwa FMA juga mampu memanfaatkan sumber $\mathrm{P}$ organik, misalnya dalam bentuk fitat (Widiastuti, 2004). Dengan demikian, hasil penelitian ini memperlihatkan bahwa vermikompos dapat berfungsi sebagai sumber hara $\mathrm{P}$ organik yang diperlukan untuk pembentukan dan perkembangan simbiosis tersebut menggantikan fungsi pupuk buatan. Selain itu, vermikompos juga mengandung populasi jasad hidup yang tinggi (Aira et al., 2006; Knapp et al., 2010) dan berpengaruh positif terhadap pembentukan dan perkembangan FMA. Hameeda et al. (2007) melaporkan bakteri yang diisolasi dari kompos jika diinokulasikan bersama-sama Glomus sp. dapat meningkatkan pertumbuhan dan kolonisasi FMA pada akar tanaman sorghum. Hal tersebut mengindikasikan bahwa vermikompos juga mempercepat perkecambahan spora dan lebih dininya kolonisasi FMA pada akar kudzu.

Pengaruh positif vermikompos terhadap kolonisasi FMA pada akar tanaman kudzu dalam penelitian ini lebih tinggi jika dibandingkan dengan hasil penelitian Fitriatin et al. (2003) yang menggunakan tanaman jagung. Mereka memberikan $50 \mathrm{~g}$ vermikompos per tanaman jagung, bobot tersebut terlalu tinggi sehingga berpengaruh buruk terhadap kolonisasi akar yang ditunjukkan dengan aras kolonisasi akar yang hanya mencapai $72 \%$. Pada bobot yang lebih rendah dalam penelitian ini, peningkatan bobot vermikompos berkadar $\mathrm{P}$ rendah ternyata tidak berdampak negatif terhadap kolonisasi akar. Hasil penelitian ini dengan demikian memperkuat hasil penelitian sebelumnya yang dilakukan oleh Bressan (2002).
Bobot vermikompos dari masing-masing diameter membentuk hubungan kuadratik dengan kolonisasi akar dan jumlah spora G. etunicatum (Gambar 4 dan 5). Bobot optimum vermikompos berukuran < $250 \mu \mathrm{m}$ adalah 150.57 dan $171.41 \mathrm{mg}$ untuk menghasilkan kolonisasi dan jumlah spora tertinggi (Tabel 2). Feldman et al. (2009) mengemukakan bahwa perkembangan FMA dipengaruhi oleh unsur hara $\mathrm{P}$, dalam batas tertentu penambahan unsur $\mathrm{P}$ meningkatkan pembentukan simbiosis MA. Semakin kecil ukuran sebuah benda semakin besar luas permukaannya sehingga menjamin proses pertukaran atau pelepasan hara yang semakin intensif (Havlin et al., 2005). Vermikompos yang memiliki diameter butir kecil berarti memiliki luas permukaan yang lebih besar untuk mempertukarkan dan menyediakan bentuk-bentuk hara yang dapat segera diserap tanaman (Chaoui et al., 2003). Pengaruh positif vermikompos dengan diameter yang semakin kecil dibatasi oleh bobotnya. Kombinasi inokulasi FMA dengan pemberian vermikompos pada bobot rendah (5\%), dengan ukuran diameter butir yang sama, dilaporkan meningkatkan pertumbuhan tanaman sorghum namun pada bobot tinggi (20 \%) justru berpengaruh negatif (Cavender et al., 2003). Hal tersebut dapat digunakan untuk menjelaskan mengapa vermikompos berukuran $<250 \mu \mathrm{m}$ menghasilkan pengaruh yang positif pada pertumbuhan tanaman kudzu dan perkembangan simbiosis MA $G$. etunicatum sampai pada batas bobot $150-172 \mathrm{mg}$ (Tabel 2).

Vermikompos berukuran $>250 \mu \mathrm{m}$ harus diberikan dengan bobot yang lebih tinggi untuk menghasilkan pengaruh yang kurang lebih sama baiknya dengan yang berukuran $<250 \mu \mathrm{m}$. Namun demikian, ukuran tepung tulang yang lebih kecil meningkatkan proporsi bahan yang harus disingkirkan. Proporsi bobot bahan berukuran $<250 \mu \mathrm{m}$ jauh lebih sedikit dibandingkan bobot tepung tulang secara keseluruhan. Ukuran yang kecil juga meningkatkan proporsi bahan yang tercuci dalam periode pertumbuhan tanaman dalam pot dibandingkan dengan ukuran bahan yang lebih besar. Ukuran yang kecil dengan demikian tidak menguntungkan jika digunakan dalam jangka panjang. Ukuran yang halus juga berpotensi meningkatkan volume air yang dipegang sehingga dapat memperlambat sporulasi. Selain itu, penyaringan vermikompos memerlukan alokasi tenaga kerja dan waktu sehingga juga meningkatkan biaya produksi.

Kolonisasi akar membentuk hubungan linier positif dengan jumlah spora G. etunicatum (Gambar 6).Vermikompos dilaporkan mengandung substansi 


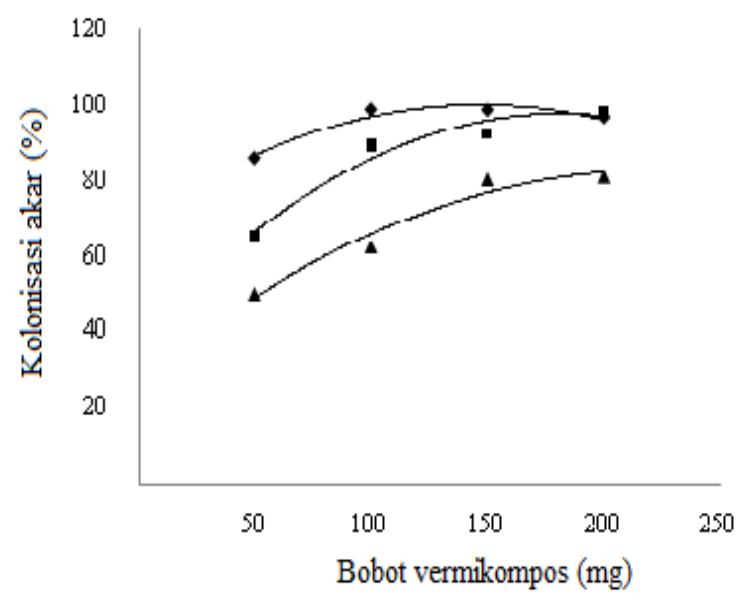

Gambar 4. Hubungan antara bobot vermikompos dan kolonisasi FMA G. etunicatum pada akar tanaman kudzu umur 12 mst. Garis regresi diameter vermikompos $<250 \mu \mathrm{m}(\diamond) \mathrm{y}=-0.001 \mathrm{x}^{2}+0.42 \mathrm{x}+69.14$ $\left(\mathrm{R}^{2}=0.94\right) ; 250-500 \mu \mathrm{m}(\mathbf{\square}) \mathrm{y}=-0.001 \mathrm{x}^{2}+0.65 \mathrm{x}+38.50$ $\left(\mathrm{R}^{2}=0.96\right) ;$ dan $>500 \mu \mathrm{m}(\mathbf{\Delta}) \mathrm{y}=-0.001 \mathrm{x}^{2}+0,51 \mathrm{x}+26.86$ $\left(\mathrm{R}^{2}=0.96\right)$

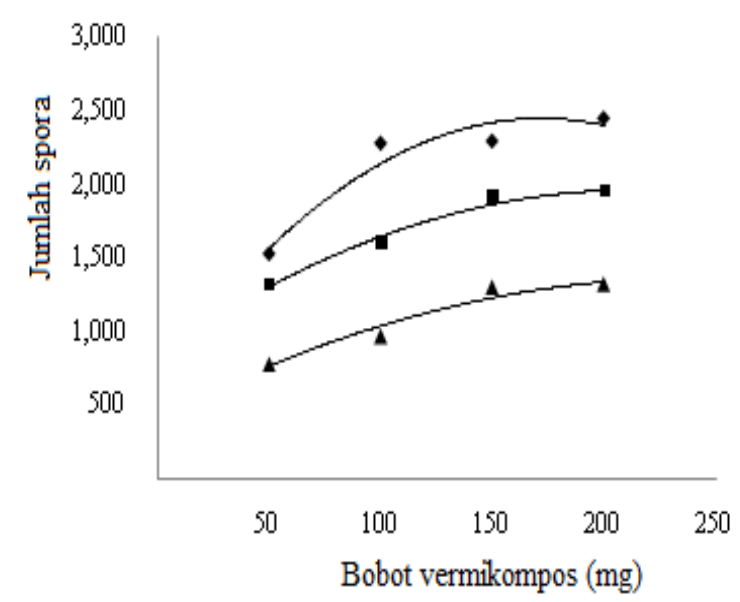

Gambar 5. Hubungan antara bobot vermikompos dan jumlah spora $G$. etunicatum dalam medium tumbuh tanaman kudzu umur 12 mst. Garis regresi diameter vermikompos $<250 \mu \mathrm{m}(\diamond) \mathrm{y}=-0.06 \mathrm{x}^{2}+20.50 \mathrm{x}+695.8$ $\left(\mathrm{R}^{2}=0.93\right) ; 250-500 \mu \mathrm{m}(\mathbf{\square}) \mathrm{y}=-0.02 \mathrm{x}^{2}+10.62 \mathrm{x}+831.7$ $\left(\mathrm{R}^{2}=0.98\right) ;$ dan $>500 \mu \mathrm{m}(\mathbf{\Delta}) \mathrm{y}=-0.02 \mathrm{x}^{2}+8.09 \mathrm{x}+394.4$ $\left(\mathrm{R}^{2}=0.95\right)$.

Tabel 2. Bobot optimal vermikompos untuk menghasilkan kolonisasi akar dan jumlah spora G. etunicatum pada setiap kelas diameter vermikompos

\begin{tabular}{lcccccc}
\hline \multirow{2}{*}{ Peubah tanaman } & \multicolumn{4}{c}{ Bobot optimal untuk setiap kelas diameter vermikompos } \\
\cline { 2 - 7 } & \multicolumn{2}{c}{$<250 \mu \mathrm{m}$} & \multicolumn{2}{c}{$250-500 \mu \mathrm{m}$} & \multicolumn{2}{c}{$>00 \mu \mathrm{m}$} \\
\hline Kolonisasi 12 mst (\%) & 150.00 & $(100)$ & 152.52 & $(96)$ & 229.95 & $(85)$ \\
Jumlah spora (buah) & 171.41 & $(2453)$ & 213.37 & $(1965)$ & 240.78 & $(1368)$ \\
\hline
\end{tabular}

Keterangan : Angka dalam kurung menunjukkan aras kolonisasi dan jumlah spora

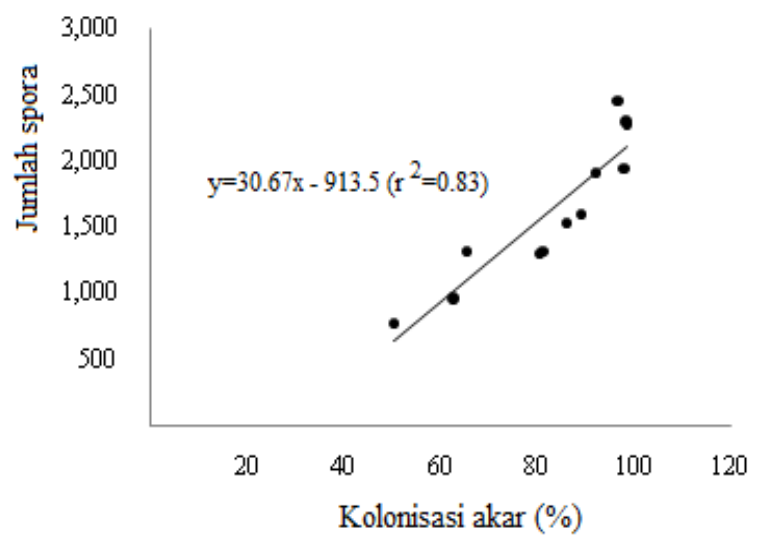

Gambar 6. Hubungan antara kolonisasi akar dan jumlah spora G. etunicatum

biologis aktif dalam bentuk auksin yang berpengaruh positif terhadap pembentukan akar (Canellas et al., 2003). Hal tersebut dapat digunakan untuk menjelaskan lebih baiknya pengaruh vermikompos terhadap bobot kering akar dibandingkan dengan larutan pupuk buatan. Meningkatnya pertumbuhan akar menjamin serapan dan translokasi hara dari medium tumbuh untuk pembentukan biomassa tanaman. Meningkatnya pertumbuhan akar juga berpotensi meningkatkan total permukaan yang dapat dikolonisasi oleh FMA. Hifa yang mengkolonisasi kemudian menjulur ke luar dari akar dan membentuk hifa ekstraradikal yang merupakan organ untuk pembentukan spora FMA (Smith and Read, 2008). Semakin banyak hifa ekstraradikal berpotensi meningkatkan jumlah spora dalam medium tumbuh, jika kondisi lingkungannya mendukung. Hal ini dapat digunakan untuk menjelaskan adanya hubungan linier positif antara kolonisasi akar dengan jumlah spora G. etunicatum.

Hasil penelitian ini memperlihatkan bahwa pemberian vermikompos menghasilkan keuntunglegum dan jumlah inokulum FMA. Peningkatan biomassa tanaman dapat disebabkan oleh semakin banyaknya pembentukan organ vegetatif tanaman yang dengan kata lain meningkatkan potensi penuan ganda yaitu meningkatkan biomassa tanaman 
tupan tanah oleh tanaman tersebut. Peningkatan biomassa tanaman legum penutup tanah juga menunjukkan potensi penyediaan hijauan untuk pakan ternak. Peningkatan inokulum FMA berarti meningkatkan potensi penyediaan inokulan atau pupuk hayati FMA untuk mengurangi kebutuhan pupuk buatan.

\section{KESIMPULAN DAN SARAN}

Vermikompos merupakan sumber hara $\mathrm{P}$ yang pengaruhnya lebih baik dibandingkan pupuk buatan untuk memproduksi biomassa legum penutup tanah dan inokulum G. etunicatum. Pengaruh positif vermikompos ditentukan oleh ukuran diameter dan bobot yang diberikan. Semakin halus ukuran diameternya semakin sedikit bobot yang harus diberikan dan sebaliknya untuk yang ukuran diameternya lebih besar. Penggunaan vermikompos untuk memproduksi biomassa legum penutup tanah dan inokulum G. etunicatum hendaknya memperhatikan aspek karakteristik fisikokimia, ketersediaan bahan, harga dan tenaga kerja yang tersedia serta tujuan akhir produksi inokulum dalam jangka pendek atau jangka panjang. Ditinjau dari aspek ekonomi, khususnya biaya produksi, dan tujuan jangka panjang maka vermikompos dengan ukuran diameter lebih besar lebih direkomendasikan dibandingkan dengan yang berukuran kecil.

\section{SANWACANA}

Ucapan terima kasih disampaikaan kepada Sub Direktorat Ketenagaan Direktorat Jenderal Pendidikan Tinggi Kementrian Pendidikan Nasional Republik Indonesia yang telah memberikan beasiswa BPPS kepada penulis pertama untuk mengikuti program S3 pada Sekolah Pascasarjana IPB.

\section{DAFTAR PUSTAKA}

Aira, M., F. Monroy, and J. Domínguez. 2006. Changes in microbial biomass and microbial activity of pig slurry after the transit through the gut of the earthworm Eudrilus eugeniae (Kinberg, 1867). Biol. Fertil. Soils 42:371-376.

Bachman G.R. and J.D. Metzger. 2008. Growth of bedding plants in commercial potting substrate amended with vermicompost. Biores. Technol. 99: 3155-3161

Bressan, W. 2002. The interactive effect of phosphorus and nitrogen on "in vitro" spore germination of Glomus etunicatum Becker and Gerdemann, root growth and mycorrhizal colonization. Braz. J. Microbiol. 32: 276 -280 .
Canellas L.P., F.L. Olivares, A.L. Okorokova-Façanha, and A.R. Façanha. 2003. Humic acids isolated from earthworm compost enhance root elongation, lateral root emergence, and plasma membrane $\mathrm{H}^{+}$-ATPase activity in maize roots. Plant Physiol. 130:19511957

Cavender, N.D., R.M. Atiyeh, and M. Kneel. 2003. Vermicompost stimulates mycorrhizal colonization of roots of Sorghum bicolor at the expense of plant growth. Pedobiologia 47: 85-89.

Chaoui H.I., L.M. Zibilske, and T. Ohno. 2003. Effects of earthworm casts and compost on soil microbial activity and plant nutrient availability. Soil Biol. Biochem. 35: 2295-302.

Douds D.D., L. Galvez, M. Franke Snyder, C. Reider, and L.E. Drinkwater. 1997. Effect of compost addition and crop rotation point upon VAM fungi. Agric. Ecosyst. Environ. 65:257-266.

Feldmann F., I. Hutter, and C. Schneider. 2009. Best production practice of arbuscular mycorrhizal inoculum. Soil Biology 18:319-335.

Ferreras L., E. Gomez, E. Toresani, I. Firpo, and R. Rotondo. 2006. Effect of organic amendments on some physical, chemical and biological properties in a horticultural soil. Biores. Technol. 97:635-640

Fitriatin B.N., M.R. Setiawati, and R. Hindersah. 2003. Aplikasi pupuk organik (kascing dan ekstrak cacing) serta cendawan mikoriza arbuskula terhadap populasi mikroba di rizosfir, kolonisasi mikoriza, pertumbuhan dan hasil tanaman jagung manis pada Ultisols. In: T. Simarmata T, D.H. Arief, Y.H. Sumarni, R. Hindersah, A. Azirin, and A.M. Kalay (Eds). Teknologi Produksi dan Pemanfaatan Inokulan Endo -Ektomikoriza untuk Pertanian, Perkebunan, dan Kehutanan. Prosiding Seminar Nasional Mikoriza, Bandung 16 September 2003. Asosiasi Mikoriza Indonesia dan Universitas Padjajaran. pp. 32-40.

Hameeda, B., M. Srijana, O.P. Rupela, and G. Reddy. 2007. Effect of bacteria isolated from composts and macrofauna on sorghum growth and mycorrhizal colonization. World J. Microbiol. Biotechnol. 23: 883-887.

Havlin J.L., J.D. Beaton, S.L. Tisdale, and W.L. Nelson. 2005. Soil Fertility and Fertilizers. An Introduction to Nutrient Management. $7^{\text {th }}$ ed. Prentice Hall, New Jersey USA.

Knapp B.A., M. Ros, and H. Insam. 2010. Do composts affect the soil microbial community?. In: H. Insam, I. Franke-Whittle, M. Goberna (Eds). Microbes at Work - From Wastes to Resources. Springer Verlag, Heidelberg. pp. 271-291.

Ndegwa P.M. and S.A. Thompson. 2001. Integrating composting and vermicomposting in the treatment of 
bioconversion of biosolids. Biores. Technol. 76: 107 -112 .

Roldan A. and J. Albaladejo. 1993. Vesicular-arbuscular mycorrhiza (VAM) fungal populations in Xeric Torriorthent receiving urban refuse. Soil. Biol. Biochem. 25:451-456.

Sainz M.J. and N.T. Taboada. 1996. Comparative effects of earthworm cast, a composted municipal refuse and a soluble $\mathrm{P}$ fertilizer on yield and arbuscular infection of Glycine max L. In: C. Azcon-Aguilar and J.M. Barea (Eds). Mycorrhizas in Integrated Systems from Genes to Plant Development. Proc. of the $4^{\text {th }}$ European Symposium on Mycorrhiza. Directorat General XII (Science, Research and Development), European Commision. Brussels, Luxembourg. pp. 588-590.
Sainz, M.J., M.T. Taboada-Castro, A. Vilarino. 1998. Growth, mineral nutrition and mycorrhizal colonization of red clover and cucumber plants grown in soil amended with composted urban wastes. Plant Soil 205: 85-92.

Singh, A. and S. Sharma. 2003. Effect of microbial inocula on mixed solid waste composting, vermicomposting and plant response. Compost Science \& Utilization 11:190-199.

Smith S.E. and D.J. Read. 2008. Mycorrhizal Symbiosis. $3^{\text {rd }}$ ed. Academic Press. San Diego, USA.

Widiastuti, H. 2004. Biologi interaksi cendawan mikoriza arbuskula kelapa sawit pada tanah asam sebagai dasar pengembangan teknologi aplikasi dini. Disertasi. Sekolah Pascasarjana, IPB, Bogor. 